\title{
PReS-FINAL-2055: Is there a necessity for patients with JIA to wear orthopedic insoles?
}

\author{
F Kreuzpointner ${ }^{1,2^{*}}$, M Hartmann², A Schwirtz ${ }^{1}$, JP Haas ${ }^{2}$ \\ From 20th Pediatric Rheumatology European Society (PReS) Congress \\ Ljubljana, Slovenia. 25-29 September 2013
}

\section{Introduction}

It is often discussed whether patients with juvenile idiopathic arthritis (JIA) should wear orthopedic insoles or not. The functions of insoles are to minimize pain or to assist foot deformities. JIA often goes along with foot impairments [1,2] describe different deviation and deformities which can develop of various pattern of foot joint involvements, like pes valgoplanus or hallux rigidus.

\section{Objectives}

The aim of the study was to analyze the peak plantar pressure distribution of a well described cohort of JIA patients with an active symmetrical ankle joint arthritis and no history of foot involvement. This setting enables to study joint loadings on healthy tissue (foot joints) due to arthritis in a superior joint (ankle joint).

\section{Methods}

Twenty two patients $(14.4 \pm 4.1 \mathrm{a}, 153.5 \pm 12.5 \mathrm{~cm}, 46.7$ $\pm 14.4 \mathrm{~kg}$ ) with a symmetrical ankle joint arthritis with the subtypes sero-negative polyarticular JIA $(\mathrm{n}=16)$ and systemic JIA $(\mathrm{n}=6)$ and a cohort of healthy subjects $(\mathrm{n}=15,11.0 \pm 2.0 \mathrm{a}, 147.0 \pm 13.0 \mathrm{~cm}, 38.1 \pm 9.9$ $\mathrm{kg}$ ) are included in this retrospective study design. Each subject had to walk five times on each side over a four sensors $/ \mathrm{cm}^{2}$ pressure distribution plate (Emed, Munich, Germany). For analysis the foot was divided into eleven regions of interests.

\section{Results}

This abstract shows the loading of each metatarsal-head (MH1(medial) - MH5 (lateral)) (Tab.1). Patients have statistical significant higher peak pressure values in the forefoot except under MH3. Further on patients have a deviating pressure distribution along the transversal arch with the highest loads under MH5. (Table 1)

\section{Conclusion}

The patients included in this study suffer from an active ankle joint arthritis. They have significant higher joint loading under healthy tissue of the foot in comparison to the controls. This might be a reason for prescribing orthopedic insoles during a period of an active arthritis. The lateral shift of the peak pressure distribution within the patients in the transversal arch indicates that it is important to control the foot function and pressure distribution not only in patients with a history of foot impairment. Orthopedic insoles might be a valuable therapeutic treatment to protect healthy tissue during a period of active arthritis.

Table 1 shows the difference in peak pressure distribution between patients and controls within the metatarsal-phalangeal-joints 1-5.

\begin{tabular}{ccccccc}
\hline \multicolumn{2}{c}{$[\mathrm{kpa}]$ mean \pm SD } & MH1 & MH2 & MH3 & MH4 & MH5 \\
\hline Patients & Left & $\mathbf{2 3 1 . 0 \pm 1 3 0 . 3}$ & $\mathbf{3 3 3 . 2} \pm \mathbf{2 3 4 . 3}$ & $293.1 \pm 176.3$ & $\mathbf{3 2 4 . 1} \pm \mathbf{2 2 0 . 8}$ & $\mathbf{4 1 0 . 3} \pm \mathbf{3 6 2 . 7}$ \\
\hline Control group & Left & $\mathbf{1 3 6 . 8} \pm \mathbf{3 6 . 6}$ & $\mathbf{2 0 6 . 7} \pm \mathbf{6 3 . 9}$ & $212.3 \pm 75.2$ & $\mathbf{1 6 5 . 7} \pm \mathbf{6 8 . 1}$ & $\mathbf{1 4 1 . 2} \pm \mathbf{1 0 3 . 3}$ \\
\hline Patients & Right & $\mathbf{2 5 7 . 8} \pm \mathbf{1 6 7 . 6}$ & $\mathbf{3 7 6 . 1} \pm \mathbf{3 2 4 . 8}$ & $291.4 \pm 208.5$ & $\mathbf{2 8 1 . 5} \pm \mathbf{1 8 4 . 8}$ & $\mathbf{3 9 0 . 8} \pm \mathbf{3 7 6 . 3}$ \\
\hline Control group & Right & $\mathbf{1 5 4 . 0} \pm \mathbf{4 3 . 0}$ & $\mathbf{2 1 6 . 5} \pm \mathbf{6 7 . 6}$ & $211.8 \pm 61.0$ & $\mathbf{1 6 3 . 2} \pm \mathbf{4 8 . 3}$ & $\mathbf{1 2 0 . 2} \pm \mathbf{7 7 . 9}$ \\
\hline
\end{tabular}

Numbers in bolt are statistical significant ( $p<0.05$, student's t-test).

\footnotetext{
${ }^{1}$ Biomechanics in sport, Technische Universität München, Munich, Germany

Full list of author information is available at the end of the article
} 


\section{Disclosure of interest}

None declared.

\section{Acknowledgements}

The authors want to thank the "Deutsche Kinder-Rheumastiftung" for financial support.

\section{Authors' details}

${ }^{1}$ Biomechanics in sport, Technische Universität München, Munich, Germany.

${ }^{2}$ Deutsches Zentrum für Kinder-und Jugendrheumatologie, Garmisch

Partenkirchen, Germany.

Published: 5 December 2013

\section{References}

1. Dekker M, et al: Clin Exp Rheumatol 2010, 28(6):905-911.

2. Truckenbrodt H, et al: Clin Exp Rheumatol 1994, 12(Suppl 10)

doi:10.1186/1546-0096-11-S2-P68

Cite this article as: Kreuzpointner et al:: PReS-FINAL-2055: Is there a

necessity for patients with JIA to wear orthopedic insoles? Pediatric

Rheumatology 2013 11(Suppl 2):P68.

Submit your next manuscript to BioMed Central and take full advantage of:

- Convenient online submission

- Thorough peer review

- No space constraints or color figure charges

- Immediate publication on acceptance

- Inclusion in PubMed, CAS, Scopus and Google Scholar

- Research which is freely available for redistribution

Submit your manuscript at www.biomedcentral.com/submit
C Biomed Central 